\title{
Effects of summer and dormant pruning time on the vegetative growth, yield, fruit quality and carbohydrate contents of two peach cultivars
}

\author{
Ali İkinci $^{1 *}$, Ali Kuden ${ }^{2}$ and Bekir Erol AK ${ }^{1}$ \\ ${ }^{1}$ Department of Horticulture, Faculty of Agriculture, Harran University, 63300 Şanlıurfa, Turkey. \\ ${ }^{2}$ Department of Horticulture, Faculty of Agriculture, Çukurova University, 01330 Adana, Turkey.
}

Accepted 29 November, 2013

\begin{abstract}
Mature "Earlyred" and Glohaven" peach [Prunus persica (L.) Batsch] trees on peach seedling rootstocks were dormant and summer pruned (June, July, August and September). Average shoot length was lower in the second year than in first year; whereas, shoot diameter was higher in the second year than in first year. Summer pruning treatments reduced shoot growth, but increased shoot diameter. Generally, the control and dormant pruned trees had the highest trunk cross-sectional area (TCSA) increment and yield efficiency (yield per trunk cross-sectional area). Summer pruned trees had a higher average fruit weight and soluble solids content than dormant pruned or control trees but at the two experimental years, fruit acidity showed no consistent response to pruning treatments. Dormant and summer pruning treatments had different effects on carbohydrate contents of peach trees. Generally, control and dormant pruned trees had higher carbohydrate content than summer pruned trees. Earlier summer pruning (June or July) lowered carbohydrate content more than late summer pruning.
\end{abstract}

Key words: Peach, Prunus persica, pruning, dormant pruning, summer pruning, carbohydrate contents.

\section{INTRODUCTION}

The effects of summer pruning deciduous fruit trees have been well-documented over the past decade. Much attention has been directed toward apple, but recent investigations have focused also on peach trees (Miller, 1987). Summer pruning of peaches has been used to control tree size, control tree shape, and redirect tree growth. However, the responses of peaches have been inconstant with reports of increased vegetative growth, decreased vegetative growth, and prolonged growing period (Rom and Ferree, 1985). Summer pruning has long been used as a management method for fruit trees.
It was shown to be a value method of controlling tree growth (Day et al., 1989, Íkinci, 1999; Hossain et al., 2006; Demirtaş et al., 2010a; Bayazit et al., 2012), increasing flowering (Day et al., 1989), increasing fruit color (Taylor and Ferree, 1984; İkinci, 1999; Hossain and Mizutani, 2008; Bayazit et al., 2012), increasing soluble solids concentration (SSC) (İkinci, 1999; Miller et al., 2001; Hossain et al., 2006; Demirtaş et al., 2010a), increasing flower bud formation (Miller, 1982) and decreasing titratable acid (TA) content (Íkinci, 1999; Hossain et al., 2006, Hossain and Mizutani, 2008).

\section{${ }^{*}$ Corresponding author. E- mail: aliikinci@harran.edu.tr. Tel: +90 41431837 05. Fax:+90 4143183682.}

Abbreviations: SSC, Soluble solids concentration; TA, titratable acid; TCSA, trunk cross-sectional area; PPFD, photosynthetic photon flux density; SRS, soluble reducing sugars; IHC, insoluble hydrolysable carbohydrates. 
Disadvantage of summer pruning include reduced cold hardiness of flower buds (Marini, 1986), delayed defoliation (Marini, 1986; İkinci, 1999), carbohydrate levels in the tree (Marini, 1986; Clair-Maczulajtys et al., 1994; Moing et al., 1994), fruit size (Erez, 1984; Myers and Ferree, 1984; Taylor and Ferree, 1984; Marini, 1985), and trunk enlargement (Marini, 1985).

Recent reports indicated that the response will vary with time, method, and cultivar. Such differences in results can probably be attributed to differences in timing and severity of pruning, and because, in some cases, summer pruning was used as a replacement for dormant pruning rather than as a supplement (Day et al., 1989).

In several cases, studies with apple and peach have indicated that summer pruning may not suppress shoot growth more than unpruned or dormant pruned trees (Myers and Ferree, 1983; Marini, 1985). Late summer pruning of peach trees -at a time when stems, fruits, and roots are still growing- theoretically could remove 35 to $45 \%$ of the total tree leaf area. The significant loss of leaf are on summer-pruned trees may lead to reduction in the carbohydrate and nutrient elements concentrations in remaining tissues and thus limit growth of tree. Satoh and Ohyama (1977) reported that summer pruning decreased carbohydrate concentration in stem and root of mulberry, and reduced the leaf carbohydrate concentrations by about $30 \%$ during the 45 -day period after pruning (Taylor and Ferree, 1986).

Summer pruning of peach are com-monly said to have many advantages over dormant pruning, including control of tree size and shape, im-proved light distribution in tree canopy, advantages fruit maturity, compressed harvest period, improved fruit size and color, improved flower bud cold hardiness, reduced pruning expenses, and suppressed tree vigor (Marini and Barden, 1987). This study was conducted to compare the effects of dormant pruning, preharvest summer pruning and post harvest summer pruning on shoot growth, yield, fruit quality, and carbohydrate levels of two peach cultivars.

\section{MATERIALS AND METHODS}

Summer pruning (pruning) experiments were conducted on mature trees of an early and mid-season peach "Earlyred" and "Glohaven" on peach seedling rootstocks growing at the Koruklu Research Station, Sanlıurfa. All trees were planted at a $6 \times 4 \mathrm{~m}$ spacing (416 trees ha $^{-1}$ ) trained to a central leader system, mini-sprinkle-irrigated, and they received routine horticultural care. The soil is a silty-clay and the trees received no fertilizer during the course of the study. Every peach tree on seedling rootstocks was subjected to six pruning treatments. A randomized complete block design with three single tree replications of peach treatment was used for each cultivar. The following treatments were applied to trees: a) Control (unpruned); b) pruned 15 June; c) pruned 15 July; d) pruned 15 Aug.; and e) pruned 15 Sept. and dormant pruning (at the beginning of every year).

Summer pruning consisted of thinning cuts to remove vigorous, upright, current season shoots, and severely heading back current season shoots to about $10 \mathrm{~cm}$ stubs in the top and center of the tree (Myers, 1993; İkinci, 1999). In addition, diseased and broken branches were also removed from trees (Marini, 1986; Küden and Kaşka, 1995; İkinci, 1999; Hossain and Mizutani, 2008). All summer pruned trees received normal dormant hand-pruning in January. Summer pruning consisted of cutting all branches to the lowest lateral on 2-year old wood resulting from a previous season's pruning cut (15). $\approx 50 \%$ of the current seasons' shoot growth was removed by the each summer pruning treatments. Control trees received only light dormant pruning with thinning-out cuts.

The fresh weight of prunings was determined for all treatments at each pruning date. Unwanted scaffold limbs were removed from all trees during the pruning seasons. The weight of fruit from each tree was recorded. Fruit were harvested all trees per treatment at the optimum mature stage and 30 fruit samples were taken for some fruit analysis. Ten shoots at $1.4 \mathrm{~m}$ above ground were selected from around each tree for growth measurements. The terminal and lateral shoots were measured prior to summer pruning treatments and in November. Shoot diameter was measured at $2 \mathrm{~cm}$ from the shoot base. At fruit harvest, trunk diameter was measured at $30 \mathrm{~cm}$ above the soil surface to calculate trunk cross-sectional area (TCSA). Trunk circumference measurements at $30 \mathrm{~cm}$ above the ground were taken annually at the beginning and end of the growing season and expressed as trunk cross-sectional area. The TCSA and shoot growth were determined by Marini (1986).

A random sample of 40 mid terminal shoot was collected from each tree (at the beginning of rest period/in Dec.) and dried at $70^{\circ} \mathrm{C}$ for at least $72 \mathrm{~h}$ than frozen at $-18^{\circ} \mathrm{C}$, lyophilized, and stored in a desiccators at $-18^{\circ} \mathrm{C}$ for carbohydrate analysis. The reduced sugar, total sugar and starch contents were determined by dinitrofenol and anthron methods (Kaplankiran, 1984). Data were evaluated by analysis of variance with Minitab 16.1.0 Statistics software package. When the F- test was significant, means were separated by Duncan's multiple range test (DMRT) at $p<0.05$. An arcsin squareroot transformation was performed on percent data.

\section{RESULTS AND DISCUSSION}

\section{Average shoot length and diameter}

Results for average shoot length and shoot diameter of treatments are presented in Table 1. Shoot length and diameter were affected by the pruning treatments in two years. The average shoot length of unpruned (control) Earlyred trees was significantly longer than those of dormant pruned and summer pruned trees. Generally, average shoot length was higher for control and dormant trees than summer pruned trees at the two peach cultivars, except that pruning results of Glohaven in the experiment's first year. Average shoot length of all dormant pruned trees was decreased 6-7\% compare to unpruned plants. Delayed summer pruning reduced shoot length more than in early pruning because of less regrowth.

Summer pruning reduced shoot diameter increase, but generally the shoot diameter increased for all peach trees summer pruned in the second year more than summer pruned in the first year (Table 1). It has been reported previously that "Redskin" shoot pruned in July was significantly thicker than shoots pruned in August (Myers, 1993). Brown and Harris (1958) have observed more regrowth on July pruned shoots than on August pruned peach shoots. Elfving (1976) found that early summer pruning of "Delicious" apple trees increased total shoot 
Table 1. The influence of summer and dormant pruning treatments on average shoot length and shoot diameter.

\begin{tabular}{lcccc}
\hline \multirow{2}{*}{ Pruning treatment } & \multicolumn{3}{c}{ Average shoot length $(\mathbf{c m})$} & \multicolumn{3}{c}{ Shoot diameter $(\mathbf{m m})$} \\
\cline { 2 - 5 } & $\mathbf{1}^{\text {st }}$ year & $\mathbf{2}^{\text {nd }}$ year & $\mathbf{1}^{\text {st }}$ year & $\mathbf{2}^{\text {nd }}$ year \\
\hline Earlyred & & & & \\
Control & $84.55 \mathrm{a}^{\mathrm{z}}$ & $77.48 \mathrm{a}$ & $10.9 \mathrm{a}$ & $10.6 \mathrm{ab}$ \\
Dormant & $78.64 \mathrm{ab}$ & $71.35 \mathrm{~b}$ & $9.3 \mathrm{ab}$ & $11.1 \mathrm{a}$ \\
SP-June \& DP & $58.89 \mathrm{~b}$ & $59.74 \mathrm{c}$ & $8.8 \mathrm{ab}$ & $9.1 \mathrm{~b}$ \\
SP-July \& DP & $48.15 \mathrm{bc}$ & $50.62 \mathrm{c}$ & $8.2 \mathrm{~b}$ & $8.7 \mathrm{c}$ \\
SP-Aug. \& DP & $37.84 \mathrm{c}$ & $36.08 \mathrm{~d}$ & $7.8 \mathrm{bc}$ & $8.9 \mathrm{bc}$ \\
SP-Sept. \& DP & $22.45 \mathrm{~d}$ & $26.36 \mathrm{e}$ & $7.6 \mathrm{~d}$ & $7.4 \mathrm{~d}$ \\
Glohaven & & & & \\
Control & $75.65 \mathrm{ab}$ & $82.95 \mathrm{a}$ & $11.2 \mathrm{ab}$ & $13.6 \mathrm{a}$ \\
Dormant & $80.98 \mathrm{a}$ & $70.38 \mathrm{ab}$ & $12.5 \mathrm{a}$ & $11.4 \mathrm{~b}$ \\
SP-June \& DP & $66.38 \mathrm{~b}$ & $52.72 \mathrm{~b}$ & $9.7 \mathrm{~b}$ & $10.0 \mathrm{~b}$ \\
SP-July \& DP & $54.86 \mathrm{bc}$ & $49.50 \mathrm{~b}$ & $8.9 \mathrm{bc}$ & $9.2 \mathrm{c}$ \\
SP-Aug. \& DP & $35.71 \mathrm{c}$ & $31.43 \mathrm{c}$ & $8.4 \mathrm{bc}$ & $8.8 \mathrm{~cd}$ \\
SP-Sept. \& DP & $29.27 \mathrm{~d}$ & $24.48 \mathrm{c}$ & $8.0 \mathrm{~d}$ & $8.4 \mathrm{~d}$ \\
\hline
\end{tabular}

${ }^{z}$ Mean separation within columns by Duncan's multiple range test at $5 \%$ level.

growth compared with that of unpruned trees, whereas late summer pruning decreased shoot growth. Generally, all pruning treatments reduced shoot length, and the time of summer pruning affected the regrowth which developed in the season of pruning. The vegetative responses to summer pruning seem to vary with tree vigor, cultivar, time, and type of pruning. Summer pruning and shearing generally tend to reduce tree size, but no more than a similar type of dormant pruning treatment. Several experiments have shown that summer pruning decreases shoot growth of young trees in comparison with that of either dormant or unpruned trees (Marini, 1985; Rom and Ferree, 1985; Mika and Piątkowski, 1989; İkinci, 1999; Hossain et al., 2006; Hossain ve Mizutani, 2008).

\section{Trunk cross sectional area (TCSA)}

Trunk enlargement was influenced by pruning treatments either in the $1^{\text {st }}$ and $2^{\text {nd }}$ year (Table 2). In the experiment's first and second year, summer pruning in June stimulated trunk enlargement of "Earlyred" trees. However, dormant pruned trees of Glohaven cultivar had significantly more trunk enlargement than summer pruned or control trees. Results on TCSA of two years showed that summer pruning suppressed trunk growth of two peach cultivars. Between $1^{\text {st }}$ and $2^{\text {nd }}$ year, TCSA increment was the highest by dormant pruning of Earlyred and unpruned trees of Glohaven.

Many other researchers studying on pruning of peach (Marini, 1985; Rom and Ferree, 1985; Platon and Zagrai, 1997; İkinci, 1999) and other tropical fruit varieties reported that SP decreases trunk enlargement compared to WP.

\section{Yield and yield efficiency}

The yield efficiency of two peach cultivars was affected by pruning treatments at the $1^{\text {st }}$ and $2^{\text {nd }}$ year (Table 2 ). In the experiment's $2^{\text {nd }}$ year, July summer pruned trees had the highest $(p \leq 0.05)$ yield efficiency for Earlyred cultivars, whereas September pruned and unpruned trees of Glohaven peach cultivars had the highest yield efficiency. However, control trees of Earlyred and summer pruned in September trees of Glohaven had the highest yield efficiency in the experiment's $2^{\text {nd }}$ year. It was reported in previous pruning studies that summer pruning on apple, almond, peach and apricot decreases yield efficiency compared to winter pruning. Demirtaş et al. (2010a) reported that pre-harvest and post-harvest period pruning on 'Hacıhaliloğlu' apricot variety improve the yield of trees, yet this increase is not statistically significant. Similarly, Bayazit et al. (2012) reported that there was no statistically significant difference between summer pruned and unpruned trees of peach and some nectarine varieties in terms of yield per tree.

\section{Average fruit weight}

Measurements at harvest indicated that all pruning treatment significantly affected mean fruit weight (Table 3). Likewise, fruit weight per tree was consistently affected by treatment in any cultivar. Fruit from the summer pruned trees tended to be slightly higher in weight. Market value of peach is determined primarily on 
Table 2. Effect of time of summer pruning on trunk cross-sectional area, yield and cropping efficiency of Earlyred and Glohaven peach trees.

\begin{tabular}{|c|c|c|c|c|c|c|c|}
\hline \multirow{2}{*}{ Pruning treatment } & \multicolumn{2}{|c|}{$\operatorname{TCSA}\left(\mathrm{cm}^{2}\right)$} & \multirow{2}{*}{$\begin{array}{c}\text { TCSA increment }\left(\mathrm{cm}^{2}\right)^{y} \\
2^{\text {nd }} \text { year }\end{array}$} & \multicolumn{2}{|c|}{ Yield/tree (kg) } & \multicolumn{2}{|c|}{ Yield efficiency $\left(\mathrm{kg} \mathrm{cm}^{-2} \mathrm{TCA}\right)$} \\
\hline & $1^{\text {st }}$ year & $2^{\text {nd }}$ year & & $1^{\text {st }}$ year & $2^{\text {nd }}$ year & $1^{\text {st }}$ year & $2^{\text {nd }}$ year \\
\hline \multicolumn{8}{|l|}{ Earlyred } \\
\hline Control & $156.78 a b^{2}$ & $190.23 a$ & $33.45 a$ & $20.99 b$ & $34.51 \mathrm{a}$ & $0.13 d$ & $0.18 \mathrm{a}$ \\
\hline Dormant & $130.11 \mathrm{c}$ & $162.79 c$ & $32.68 \mathrm{a}$ & $21.81 b$ & $25.96 \mathrm{bc}$ & $0.17 \mathrm{~b}$ & $0.16 a b$ \\
\hline SP-June \& DP & $171.27 a$ & $198.17 a$ & $26.9 a b$ & $19.49 b$ & $27.97 \mathrm{~b}$ & $0.11 \mathrm{e}$ & $0.14 b$ \\
\hline SP-July \& DP & $137.71 b c$ & $160.96 c$ & $23.25 b$ & $26.24 a$ & $24.51 \mathrm{bc}$ & $0.19 a$ & $0.15 a b$ \\
\hline SP-Aug. \& DP & $146.91 b$ & $167.12 \mathrm{c}$ & $20.21 c$ & $24.77 a$ & $20.78 c$ & $0.17 \mathrm{~b}$ & $0.12 \mathrm{c}$ \\
\hline $\begin{array}{l}\text { SP-Sept. \& DP } \\
\text { Glohaven }\end{array}$ & $159.88 a b$ & $185.94 b$ & $26.06 \mathrm{ab}$ & $24.74 a$ & $20.19 c$ & $0.15 \mathrm{c}$ & $0.11 \mathrm{c}$ \\
\hline Control & 130.70ab & $154.09 b$ & $23.39 \mathrm{~b}$ & $37.99 a$ & $31.02 a$ & $0.29 a$ & $0.20 \mathrm{~b}$ \\
\hline Dormant & $146.22 a$ & $175.29 a$ & $29.07 a$ & 32.62ab & $28.68 b$ & $0.22 b$ & $0.16 c$ \\
\hline SP-June \& DP & $126.67 b$ & $142.06 b$ & $15.39 d$ & $26.56 b$ & $23.74 \mathrm{c}$ & $0.21 b$ & $0.17 c$ \\
\hline SP-July \& DP & $119.64 c$ & $139.08 \mathrm{bc}$ & $19.44 \mathrm{c}$ & $26.97 b$ & $28.49 b$ & $0.23 a b$ & $0.20 \mathrm{~b}$ \\
\hline SP-Aug. \& DP & $119.29 c$ & $132.37 \mathrm{c}$ & $13.08 d$ & $25.2 b$ & $26.27 \mathrm{~b}$ & $0.21 \mathrm{~b}$ & $0.20 \mathrm{~b}$ \\
\hline SP-Sept. \& DP & $104.73 d$ & $123.15 d$ & $18.42 \mathrm{C}$ & $31.26 \mathrm{ab}$ & $27.24 b$ & $0.29 a$ & $0.22 \mathrm{a}$ \\
\hline
\end{tabular}

${ }^{\mathrm{y}} \mathrm{TCSA}$ increment= TCSA $/ 2^{\text {nd }}$ year $-\mathrm{TCSA} / 1^{\text {st }}$ year. ${ }^{2}$ Mean separation within columns by Duncan's multiple range test at $5 \%$ level.

Table 3. Average fruit weight (g), soluble solids (\%) and titratable acidity (\%) of peaches as influenced by summer or dormant pruning.

\begin{tabular}{|c|c|c|c|c|c|c|}
\hline \multirow{2}{*}{ Pruning treatment } & \multicolumn{2}{|c|}{ Average fruit weight (g/fruit) } & \multicolumn{2}{|c|}{ Soluble solids content (\%) } & \multicolumn{2}{|c|}{ Titratable acidity (\%) } \\
\hline & $1^{\text {st }}$ year & $2^{\text {nd }}$ year & $1^{\text {st }}$ year & $2^{\text {nd }}$ year & $1^{\text {st }}$ year & $2^{\text {nd }}$ yea \\
\hline \multicolumn{7}{|l|}{ Earlyred } \\
\hline Control & $49.63 b^{z}$ & $49.79 b$ & 11.50 & 14.25 & $0.52 b$ & 0.68 \\
\hline Dormant & $66.23 a b$ & 67.27ab & 9.65 & 13.25 & $0.53 a b$ & 0.75 \\
\hline SP-June \& DP & $74.00 \mathrm{a}$ & $60.31 b$ & 12.00 & 15.00 & $0.68 a b$ & 0.71 \\
\hline SP-July \& DP & $76.35 a$ & $91.84 a$ & 11.00 & 15.50 & $0.54 a b$ & 0.89 \\
\hline SP-Aug. \& DP & $83.02 a$ & $59.47 \mathrm{~b}$ & 11.55 & 13.75 & $0.76 \mathrm{a}$ & 0.77 \\
\hline SP-Sept. \& DP & $83.49 a$ & $50.89 \mathrm{~b}$ & 10.30 & 14.00 & $0.54 a b$ & 0.73 \\
\hline \multicolumn{7}{|l|}{ Glohaven } \\
\hline Control & $86.19 b$ & 85.99 & $12.60 \mathrm{ab}$ & 15.50 & $0.44 b$ & $0.74 a$ \\
\hline Dormant & $97.28 a b$ & 115.03 & $14.33 a$ & 15.60 & $0.30 \mathrm{~b}$ & $0.63 a b$ \\
\hline SP-June \& DP & $96.56 \mathrm{ab}$ & 94.75 & 13.33ab & 16.10 & $0.34 b$ & $0.69 a$ \\
\hline SP-July \& DP & $90.78 b$ & 90.79 & $11.27 \mathrm{~b}$ & 14.90 & $0.37 \mathrm{~b}$ & $0.66 \mathrm{a}$ \\
\hline SP-Aug. \& DP & $100.11 \mathrm{ab}$ & 116.58 & $14.07 a$ & 15.10 & $0.69 a$ & $0.47 b$ \\
\hline SP-Sept. \& DP & $111.90 \mathrm{a}$ & 97.00 & $13.53 a$ & 14.00 & $0.36 \mathrm{~b}$ & $0.63 \mathrm{ab}$ \\
\hline
\end{tabular}

${ }^{z}$ Mean separation within columns by Duncan's multiple range test at $5 \%$ level.

segregation of fruit into various size categories. Analysis of fruit distribution into selected representative commercial size categories revealed that at the experiment's $1^{\text {st }}$ and $2^{\text {nd }}$ year, summer pruning increased the percenttage of fruit in the largest size category.

The fruit size distribution effect of summer pruning may be the result of a decrease in total leaf area and, as a result, a decrease in total transpirational loss by tree. Such trees would use less water and be less susceptible to water stress, thereby improving fruit water status and fruit growth rate during Stage III (final swell) when the fruit have a large demand for photosynthesis and water (Chalmers and van den Ende,1975; Chalmers et al., 1975; Walsh et al., 1989; Myers, 1993). There may have been an increase in photosynthate available to fruit of summer pruned trees due to an increase in photosynthetic photon flux density (PPFD) and/or the removal of competitive sinks, that is, watersprouts. Also, improved light exposure may have strengthened fruit sink activity, thus increasing fruit size (Day et al., 1989). The smaller fruit typical of summer pruned trees probably results from a reduced pool of available assimilate, as over $20 \%$ of 
Table 4. The influence of summer pruning on concentration of water-soluble reducing sugars (SRS); water-insoluble hydrolyzable carbohydrate $(\mathrm{IHC})$; and total sugar content of shoot of Earlyred and Glohaven peach cultivars.

\begin{tabular}{|c|c|c|c|c|c|c|}
\hline \multirow{3}{*}{ Pruning treatment } & \multicolumn{6}{|c|}{ Carbohydrates by dry weight (\%) } \\
\hline & \multicolumn{2}{|c|}{ Water soluble sugars } & \multicolumn{2}{|c|}{ Hydrolyzed starch } & \multicolumn{2}{|c|}{ Total extracted $\mathrm{CHO}$} \\
\hline & $1^{\text {st }}$ year & $2^{\text {nd }}$ year & $1^{\text {st }}$ year & $2^{\text {nd }}$ year & $1^{\text {st }}$ year & $2^{\text {nd }}$ year \\
\hline \multicolumn{7}{|l|}{ Earlyred } \\
\hline Control & $3.46 \mathrm{a}^{2}$ & $3.38 b$ & $5.50 \mathrm{a}$ & $5.70 \mathrm{a}$ & $8.96 \mathrm{a}$ & $9.08 \mathrm{a}$ \\
\hline Dormant & $3.33 \mathrm{a}$ & $4.13 \mathrm{a}$ & $5.11 \mathrm{a}$ & $5.40 \mathrm{ab}$ & $8.44 \mathrm{a}$ & $9.53 \mathrm{a}$ \\
\hline SP-June \& DP & $2.98 \mathrm{~b}$ & $2.60 \mathrm{c}$ & $2.79 \mathrm{c}$ & $4.67 \mathrm{~d}$ & $5.77 \mathrm{c}$ & $7.27 \mathrm{c}$ \\
\hline SP-July \& DP & $2.65 \mathrm{c}$ & $1.80 \mathrm{~d}$ & $2.50 \mathrm{~d}$ & $4.14 \mathrm{e}$ & $5.15 \mathrm{e}$ & $5.94 \mathrm{~d}$ \\
\hline SP-Aug. \& DP & $2.53 \mathrm{~d}$ & $2.63 \mathrm{c}$ & 2. $93 \mathrm{c}$ & $5.05 \mathrm{c}$ & $5.46 \mathrm{~d}$ & $7.68 \mathrm{~b}$ \\
\hline SP-Sept. \& DP & $2.06 \mathrm{e}$ & $2.65 \mathrm{c}$ & $4.12 \mathrm{~b}$ & $5.19 \mathrm{bc}$ & $6.18 \mathrm{~b}$ & $7.84 \mathrm{~b}$ \\
\hline \multicolumn{7}{|l|}{ Glohaven } \\
\hline Control & $3.59 \mathrm{~b}$ & $3.00 \mathrm{~b}$ & $4.83 \mathrm{~b}$ & $6.68 \mathrm{~b}$ & $8.42 \mathrm{~b}$ & $9.68 \mathrm{~b}$ \\
\hline Dormant & $4.38 \mathrm{a}$ & $3.90 \mathrm{a}$ & $5.50 \mathrm{a}$ & $7.30 \mathrm{a}$ & $9.88 \mathrm{a}$ & $11.20 \mathrm{a}$ \\
\hline SP-June \& DP & $2.01 \mathrm{f}$ & $2.14 \mathrm{~d}$ & $3.22 \mathrm{e}$ & $4.75 \mathrm{c}$ & $5.23 d$ & $6.89 \mathrm{~d}$ \\
\hline SP-July \& DP & $2.44 \mathrm{e}$ & $1.86 \mathrm{f}$ & $3.70 \mathrm{~d}$ & $6.88 \mathrm{~b}$ & $6.14 \mathrm{c}$ & $8.74 \mathrm{c}$ \\
\hline SP-Aug. \& DP & $2.78 \mathrm{~d}$ & $2.04 \mathrm{e}$ & $3.80 \mathrm{~cd}$ & $4.95 \mathrm{c}$ & $6.58 \mathrm{~d}$ & $6.99 \mathrm{~d}$ \\
\hline SP-Sept. \& DP & $3.13 \mathrm{c}$ & $2.83 \mathrm{c}$ & $4.04 \mathrm{c}$ & $6.92 \mathrm{ab}$ & $7.17 \mathrm{~b}$ & $9.75 \mathrm{~b}$ \\
\hline
\end{tabular}

${ }^{2}$ Mean separation within columns by Duncan's multiple range test at $5 \%$ level.

the foliage usually is removed with pruning (Mika, 1986).

\section{Soluble solids}

Pruning treatments did not affect soluble solids contents of Earlyred peach fruits significantly in the $1^{\text {st }}$ or $2^{\text {nd }}$ year, whereas soluble solids content was affected by pruning treatment only in the $1^{\text {st }}$ year (Table 3 ). Data from this study confirm that summer or dormant pruning had inconsistent effects of peach fruit soluble solids.

According to earlier studies, Daulta et al. (1986), Hossain et al. (2004), Hossain and Mizutani (2008) reported that SP applications had increased SSC in peach. However, Niran (1981), Miller (1982), Íkinci (1999) and Bayazit et al. (2012) reported that SP applications had no significant effect on SSC of fruits in both peach and apple. Marini and Barden (1982), Taylor and Ferree (1984), Cust and Ferree (1985), Miller (1987) and Christopher et al. (1989) stated that SP applications negatively affected SSC in peach. The reduction in fruit size and fruit soluble solids associated with relatively severe SP is likely due to the reduction in total photosynthetic production of tree resulting in less carbohydrates available for the fruit.

\section{Titratable acidity}

Pruning treatments influenced fruit titratable acidity of Earlyred fruits significantly in first year, but not in the $2^{\text {nd }}$ year (Table 3). Analyses of the titratable acid contents of
Earlyred peach fruits showed that summer pruned trees generally had higher titratable acidity than dormant or unpruned trees.

Titratable acid content of all Glohaven fruits were affected by pruning treatment in both year. Summer or dormant pruning treatment increased titratable acidity of peach fruits in the $2^{\text {nd }}$ year of research. Increased titratable acidity following pruning treatment probably was related to increased light penetration into the center of trees. Similar to the results of our research, Hossain ve Mizutani (2008) reported in pruning treatments conducted on 9-years old "Akatsuki" peach varieties budding on strong rootstock in 2001-2005 that TA value decreased in trees with SP more than in those with WP.

\section{Carbohydrate contents}

Summer pruning plus dormant (winter) pruning treatments affected all carbohydrate contents of two peach cultivars (Table 4). The effects of summer or dormant pruning on carbohydrate contents of peach trees have been quite variable. Earlyred peach trees pruned to dormant or unpruned had a significantly $(p \leq 0.05)$ greater shoot water-soluble reducing sugars (SRS), insoluble hydrolysable carbohydrates $(\mathrm{IHC})$ or total extracted carbohydrate content. There was no so significant difference in carbohydrate levels between dormant pruned and control plants of Earlyred peach cultivars' at the end of two growing seasons. Especially, summer pruning in July plus dormant pruning of Earlyred peach trees had lower shoot carbohydrate contents than dor- 
mant or other summer pruning treatments except in the $1^{\text {st }}$ year. Average of all summer pruned trees shot SRS (25 and $41 \%$ ) and $\mathrm{IHC}$ (39 and 11\%) concentrations were lower than dormant pruned trees, respectively, in the $1^{\text {st }}$ and in $2^{\text {nd }}$ year.

For two cropping years, dormant pruned trees of Glohaven peach cultivars had higher carbohydrate concentration than all of summer pruned trees. There were relatively great decreases (29 to $50 \%$ ) in soluble and insoluble carbohydrates fractions between dormant pruned and summer pruned plants of Glohaven peach cultivar. Generally, early summer pruning treatments (June or July) had the lowest carbohydrate concentrations, whereas carbohydrate fractions had relatively great increases (25 to 50\%) for pruning at August or September.

Demirtaş et al. (2010b) conducted five different SP and WP treatments on 'Hacıhaliloğlu' apricot trees and found that post-harvest SP treatment had the highest increasing effect on average total sugar, reducing sugar and starch contents. In sweet cherry, one year after SP, the level of carbohydrate in trunk was lower compared to unpruned trees (Maczulajtys et al., 1994). Other studies have also shown that pruning results in quantitative changes in carbohydrate reserves. Pruning affects the concentration of reserves, by elimination of carbohydrate storage sites (Bory and Maczulajtys, 1993). Increasing the severity, summer pruning (the length of shoot removed) did not affect the concentration of water-SRS or IHC in the basal section of the "Top Red Delicious"/M9 trees 11 weeks after pruning. There was no significant effect of pruning on SRS or IHC levels in the roots (Taylor and Ferree, 1986). Greene and Lord (1983) suggested that although summer pruning may reduce carbohydrate levels enough to restrict the increase in trunk circumference, they may still be above that critical level required to reduce terminal growth.

\section{Conclusions}

Tree response to summer pruning is often variable and depends on the type of cuts (heading cuts or thinning cuts) and on the exact time of pruning in the growing season. Tree response to summer pruning is also influenced by cultivar, rootstock, tree vigor, and age. The effects of summer pruning often differ from those of dormant pruning. It appears that for summer pruning both pre-harvest and postharvest is an effective method for suppressing tree growth. If it made in 6 to 9 WAFB, it would be more effective in stimulating flower bud initiation than pruning later in the season. In this study, however, on trees summer pruned in preharvest time, sunburning on fruit increased. Our results indicate that regrowth shoots on late summer pruned trees increased winter injury. Removal of superfluous vegetative growth, that is, watersprouts, using selective thinning cuts may be a useful technique for increasing light penetration within open center peach trees. Removal of superfluous growth during final swell, however, has the potential for increasing value of marketable fruit based on fruit size. The effect of pruning treatments on tree and fruit quality can be observed within the next session. Our experience indicates that peach growers should consider SP as a standard cultural technique in the development of peach trees. In addition, our results suggest that preharvest summer pruning have a positive effect on flower bud formation on fruiting wood within the canopy.

\section{ACKNOWLEDGEMENT}

This research is supported by the University of Harran (Project No: 81), Sanliurfa-Turkey.

\section{REFERENCES}

Bayazit S, İmrak B, Küden A (2012). Effects of tipping applications on yield and fruit quality of some peach and nectarine. MKU Ziraat Fakültesi Dergisi 17:23-30.

Bory G, Clair-Maczulajtys D (1993). Reserve metabolites: An insight into tree physiology. In Physiologie des arbres et arbustes en zones arides et semi-arides. Eds. A. Riedacker, E. Dreyer, C. Pafdadnam and G. Bory. John Libbey Eurotext, France, pp. 97-115.

Brown D, Haris RW (1958). Summer pruning trees of early maturing peach varieties. Proc. Am. Soc. Hort. Sci. 72:79-84.

Chalmers DJ, Canterford RL, Jerie PH, Jones TR, Ugalde TD (1975). Photosynthesis in relation to growth and distribution of fruit in peach trees. Austral. J. Plant Physiol. 2:635-645.

Chalmers DJ, Van Den Ende BA (1975). Reappraisal of the growth and development of peach fruit. Austral. J. Plant Physiol. 2:623-634.

Christopher SW, Allnutt FJ, Miller AN, Thompson AH (1989). Nitrogen level and time of mechanized summer shearing influence long-term performance of a high-density "Redskin" peach orchard. J. Am. Soc. Hort. Sci 114:373-377.

Clair-Maczulajtys D, Sarthou C, Bory G (1994). Effect of pruning on carbohydrate distribution in the trunk of cherry (Prunus avium L.). Scientia Horticulturae 59:61-67.

Cust CR, Ferree DC (1985). Time and severity of summer pruning influences on young peach tree net photosynthesis, transpiration, and dry weight distribution. J. Am. Soc. Hort. Sci. 110:455-461.

Daulta BS, Devi S, Sing D (1986). Effect of severity pruning on yield and quality of peach cv. Sharbati. Indian J. Hort. 43:180-183.

Day KR, Dejong TM, Hewitt AA (1989). Postharvest summer pruning of 'Firebrite' nectarine trees. Hort. Sci. 24:238-240.

Demirtaş MN, Bolat İ, Ercişli S, İkinci A, Ölmez H, Şahin M, Altındağ M, Çelik B (2010a). The effects of different pruning treatments on the growth, fruit quality and yield of 'Hacıhaliloglu' apricot. Acta Sci. Pol., Hortorum Cultus 9:183-192.

Demirtaş MN, Bolat İ, Ercişli S, İkinci A, Ölmez H, Şahin M, Altındağ M, Çelik B (2010b). The effects of different pruning treatments on seasonal variation of carbohydrates in 'Hacihaliloglu' apricot cultivar. Not. Bot. Hort. Agrobot. Cluj 38:223-227.

Elfving DC (1976). Growth and fruiting responses of vigorous apple branches to pruning and branch orientation treatments. J. Am. Soc. Hort. Sci. 101:290-293.

Erez A (1984). Dwarfing peaches by pruning and by paclobutrazol. Acta Horticulturae 146:235-241.

Greene DW, Lord WJ (1983). Effects of dormant pruning, scoring and growth regulators on growth, yield and fruit quality of 'Delicious' and 'Cortland' apple trees. J. Am. Soc. Hort. Sci. 108:590-595.

Hossain ABMS, Mizutani $F$ (2008). Dwarfing peach trees and fruit quality development by using summer pruning as physiological changed 
dwarfing component. Austr. J. Basic Appl. Sci. 2:844-849.

Hossain ABMS, Mizutani F, Onguso JM (2004). Effect of summer pruning on maintaining the shape of slender spindle bush of peach tree grafted on vigorous rootstock. J. Japan. Agr. Tech. Man 11:5562.

Hossain ABMS, Mizutani F, Onguso JM, El-Shereif AR, Rutto KL (2006). Effect of summer pruning on shoot growth and fruit quality in peach trees trained as slender spindle bush type. Bulletin of the Faculty of Agriculture, Ehime University 51:9-13.

İkinci A (1999). The effect different pruning treatments on yield, quality and carbohydrate accumulation in peach, almond and apricot. Cukurova University, PhD Thesis, $213 \mathrm{p}$.

Kaplankıran M (1984). The relationships between citrus rootstocks growth and phytohormone, minerals and carbohydrate content. Cukurova University, PhD Thesis, $151 \mathrm{p}$.

Küden A, Kaşka N (1995). Effects of winter and summer pruning on the yield and fruit quality of 'Priana' and 'Beliana' apricot cultivars. Acta Horticulturae 384:455-459.

Maczulajtys D, Sarthou C, Bory G (1994). Effect of pruning on carbohydrate distribution in the trunk of cherry (Prunus avium L.). Scientia Horticulturae 59:61-67.

Marini RP (1985). Vegetative growth, yield, and fruit quality of peach as influenced by dormant pruning, summer pruning and summer topping. J. Am. Soc. Hort. Sci. 110:133-139.

Marini RP (1986). Defoliation, flower bud cold hardiness, and bloom date of peach as influenced by pruning treatments. J. Am. Soc. Hort. Sci 113:391-394.

Marini RP, Barden JA (1982). Growth and flowering of vigorous apple trees as affected by summer or dormant pruning. J. Am. Soc. Hort. Sci 107:34-39.

Marini RP, Barden JA (1987). Summer pruning of apple and peach trees. Hort. Rev. 9:351-376.

Mika A (1986). Physiological responses of fruit trees to pruning. Hort. Rev. 8:337-378.

Mika A, Piątkowski M (1989). Controlling tree size in dense plantings by winter and summer pruning. Acta Horticulturae 43:95-102.

Miller SA, Broom FD, Thorp TG, Barnett AM (2001). Effects of leader pruning on vine architecture, productivity and fruit quality in kiwifruit. Scientia Hort. 91:189-199.

Miller SS (1982). Regrowth, flowering and fruit quality of 'delicious' apple trees as influenced by summer pruning. J. Am. Soc. Hort. Sci. 107:975-978.

Miller SS (1987). Summer pruning affects fruit quality and light penetration in young peach trees. Hort. Sci. 22:390-393.

Moing A, Lafargue B, Lespinasse JM, Gaudillere JP (1994). Carbon and nitrogen reserves in prune tree shoots: effects of training system. Sci. Hort 57:99-110.
Myers SC (1993). Preharvest waterspout removal influences canopy light relations, fruit quality, and flower bud formation of "Redskin" peach trees. J. Am. Soc. Hort. Sci. 118:442-445.

Myers SC, Ferree DC (1983). Influence of time of summer pruning and limb orientation on yield, fruit size and quality of vigorous "Delicious" apple trees. J. Am. Soc. Hort. Sci. 108:630-633.

Myers SC, Ferree DC (1984). Summer pruning for size control in a high density 'Delicious'/M9 system. Acta Horticulturae 146:253-261.

Neri D, Sansavini S, Sugiyama N (1992). Summer and root pruning of split-root potted peach trees. Acta Horticulturae 322, Training Pruning Fruit Trees:177-189.

Niran $J$ (1981). Effects of time of pruning on some characteristics of peach (Prunus persica L.) cvs. Flordabelle and Flordasun. Kasetsart Univ. Bangkok (Thailand). Graduate School, Bangkok (Thailand), 111 p.

Platon I, Zagrai L (1997). The influence of training system and pruning time on growth and apple fruiting. Acta Horticulturae 451:513-518.

Rom CR, Ferree DC (1985). Time and severity of summer pruning influences on young peach tree net photosynthesis, transpiration, and dry weight distribution. J. Am. Soc. Hort. Sci. 110:455-461.

Satoh M, Ohyama K (1977). Studies on photosynthesis and translocation of photosynthate in mulberry tree. VI. Changes in amylase activity and in amount of carbohydrates in a storage organ after shoot pruning. Jap. J. Crop. Sci. 46:499-503.

Taylor BH, Ferree DC (1984). The influence of summer pruning and cropping on growth and fruiting of apple. J. Am. Soc. Hort. Sci. 109:19-24.

Taylor BH, Ferree DC (1986). The influence of summer pruning and fruit cropping on the carbohydrate, nitrogen and nutrient composition of apple trees. J. Am. Soc. Hort. Sci. 111:342-346.

Walsh CS, Alnutt FJ, Miller AN, Thompson AH (1989). Nitrogen level and time of mechanized summer shearing influence long-term performance of a high-density 'Redskin' peach orchard. J. Am. Soc. Hort. Sci. 114:373-377. 